\title{
A novel case of unilateral blepharophimosis syndrome and mental retardation associated with de novo trisomy for chromosome $3 \mathrm{q}$
}

T Cai, D A Tagle, X Xia, P Yu, X X He, L Y Li, J H Xia

\begin{abstract}
We have evaluated a 3 2/12 year old girl who presented with unilateral blepharophimosis, ptosis of the eyelid, and mental retardation. Additional dysmorphic features include microcephaly, high, narrow forehead, short stubby fingers, and adduction of the right first toe. Cytogenetic analysis showed an unbalanced karyotype consisting of $46, \mathrm{XX}$, add(7) $(\mathrm{q}+)$ that was de novo in origin. Fluorescence in situ hybridisation (FISH) using microdissected library probe pools from chromosomes 1, 2, 3, 7, and 3q26-qter showed that the additional material on $7 q$ was derived from the distal end of the long arm of chromosome 3. Our results indicate that the patient had an unbalanced translocation, $46, X X, \operatorname{der}(7) t(3 ; 7)$ (q26-qter;q+) which resulted in trisomy for distal 3q. All currently reported cases of BPES (blepharophimosis-ptosis-epicanthus inversus syndrome) with associated cytogenetic abnormalities show interstitial deletions or balanced translocations involving 3q22-q23 or 3p25.3. Our patient shares similar features to BPES, except for the unilateral ptosis and absence of epicanthus inversus. It is possible that our patient has a contiguous gene defect including at least one locus for a type of blepharophimosis, further suggesting that multiple loci exist for eyelid development. (F Med Genet 1997;34:772-776)
\end{abstract}

Keywords: blepharophimosis; ptosis; mental retardation; 3q26-qter trisomy

Blepharophimosis or shortening of the horizontal orbital fissure is a congenital eyelid malformation that is inherited in an autosomal dominant fashion. There are now more than 150 cases described with the syndrome BPES (MIM 110100') showing combined features of blepharophimosis, ptosis, and epicanthus inversus. ${ }^{2}$ BPES features include epicanthus inversus (fold curving in the mediolateral direction, inferior to the inner canthus), low nasal bridge, and ptosis of the eyelids leading to narrowing, both vertically and horizontally, of the palpebral fissures. Thus, subjects with BPES have smaller than normal eyelid openings. The ptosis is usually bilateral and symmetrical. Additional dysmorphic features of the eye include nystagmus, microphthalmos, microcornea, and stenosis of the lateral canal- iculi. Other pleiotropic features of BPES are mental retardation, notably seen in sporadic cases, and female infertility. The association with female infertility distinguishes two types of BPES, type I and type II, where in the latter type affected females are fertile, so transmission occurs through both sexes. ${ }^{34}$

Earlier findings of cytogenetic abnormalities that included balanced translocations ${ }^{5-9}$ and interstitial deletions ${ }^{10-16}$ in association with BPES suggested a chromosomal location at $3 q 22-q 23$. Subsequent linkage studies have confirmed the map location for both types of BPES to the $3 q 22-q 23$ interval, ${ }^{17-22}$ indicating the possibility that the two types of BPES are allelic or that BPES represents a contiguous gene syndrome.

We report here a 3 2/12 year old, mentally retarded girl with blepharophimosis and unilateral ptosis in addition to multiple other anomalies. Cytogenetic analysis indicated an unbalanced $7 q+$ chromosome arising from trisomy of the 3q26-qter region.

\section{Case report}

The proband was the first child of a healthy couple and there were no other sibs nor any significant family history of the disorder (fig 1). Birth weight and length were reported to be normal but no records were found. The mother and father were 25 and 27 years old, respectively, at the birth of the child. The parents are of Chinese Han descent and are phenotypically normal. However, the paternal grandparents of the patient are first cousins. The pregnancy was uncomplicated except that the mother had an episode of unconsciousness lasting for one minute during the 12th week of pregnancy. The mother had no known contact with any teratogenic agent before or during pregnancy. The child had mild hypoxia lasting for a short time at birth.

The patient was first evaluated at 13 months of age when mild mental retardation and slight

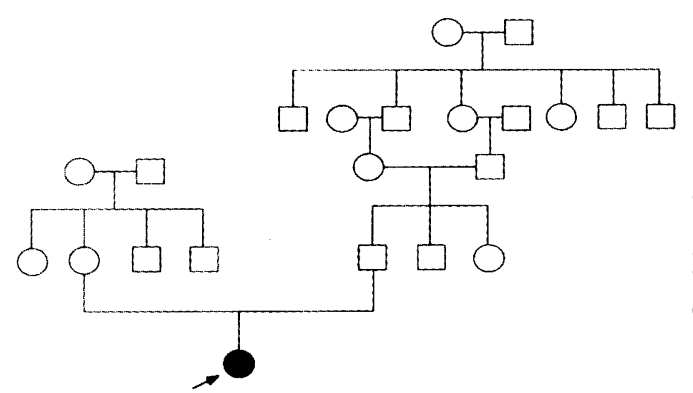

Figure 1 Pedigree of family 3673 with BPES. 


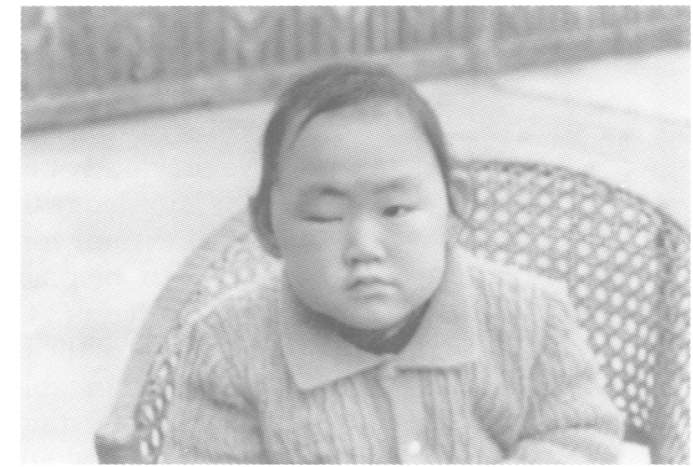

Figure 2 Anterior view of the proband aged 3 years. Note the distinctive facial features showing blepharophimosis, ptosis of the right eye, high forehead, and microcephaly. (Photograph reproduced with permission.)

ptosis of the right eyelid were noted. However, no ophthalmological examination was done at that time. She could sit unaided, but was unable to crawl. The child showed slow responses to surrounding changes despite a normal audiology screen. She also had simple vocalisation. Physical examination showed that the lungs, heart, and abdomen were normal. No limb abnormalities were found and the fontanelles have fully closed. Thirteen teeth had erupted and bone $x$ rays showed normal bone development typical of a 13 month old child.

The child was re-examined at 38 months of age. Mental retardation was quite evident and the ptosis of the right eyelid had become obvious. Vocalisation consisted of a single word. On examination her length at $93.5 \mathrm{~cm}$ and weight at $14 \mathrm{~kg}$ were normal. A length and weight of $94.2 \mathrm{~cm}$ and $13.44 \mathrm{~kg}$ is average for a 3 year old Chinese Han girl. The occipitofrontal circumference (OFC) of $46 \mathrm{~cm}$ was much smaller than normal $(<1$ st centile and comparable to the mean OFC $(46.2 \mathrm{~cm})$ for Chinese children at 18 months of age).$^{23}$ In addition the right temporal bone was smaller than the left, the occiput was flat, and the forehead was narrow (fig 2). The patient also showed blepharophimosis and ptosis of the right eyelid but there was no epicanthus inversus. The inner canthal distance (ICD) was $3.5 \mathrm{~cm}$ ( $>6$ th centile with a mean ICD $(3.284 \mathrm{~cm})$ age of a female adult) and the outer canthal distance (OCD) was 8.6

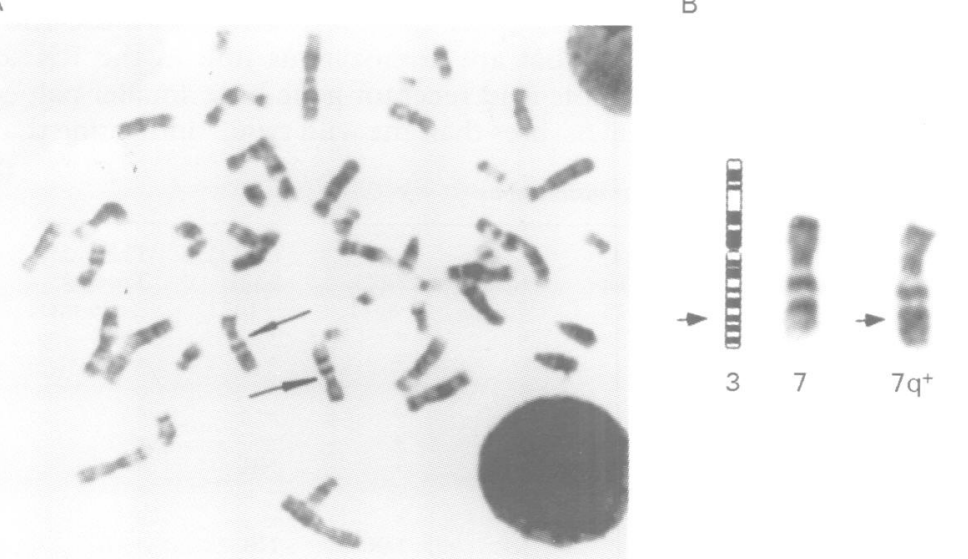

Figure 3 (A) Routine $G$ banded karyotype of the patient. The two chromosomes 7 are indicated by arrows. (B) Partial chromosome 7 karyotype is shown with the arrows indicating where the breakpoints in chromosomes 3 and 7 occurred. $\mathrm{cm}(<1$ st centile with a mean OCD $(8.672 \mathrm{~cm})$ age of a female adult). The palpebral fissure length was normal at $2.5 \mathrm{~cm}$ and the maximum vertical palpebral opening for the left eye was $0.6 \mathrm{~cm}$ compared to $0.4 \mathrm{~cm}$ for the right eye.

The proband also showed a dull face, gelasmus, hypotrichosis with a low posterior hairline, a flat nasal bridge, high but narrow palate, redundant skin on the neck, and low set and posteriorly rotated ears. Chest circumference was normal at $52.5 \mathrm{~cm}$ and the distance between the two nipples was also normal. The circumference of the abdomen was also normal at $53 \mathrm{~cm}$, and the liver and spleen were of normal size. The finger to finger distance was normal at $91 \mathrm{~cm}$. The hands were broad and the fingers were short and stubby. The second toe on the right foot overrode the third toe and adduction of the first toe was evident. Her gait was immature and clumsy. Examination of the vulva was normal. Tests for muscular tone showed the child has mild generalised hypotonia. No abnormal pathological reflexes were found.

\section{CYTOGENETICS}

Peripheral blood was set up in 72 hour cultures and the metaphase spreads were prepared for $G$ banding and high resolution staining using standard techniques. Chromosomal analysis showed an unbalanced karyotype with additional material on the terminal end of the long arm of chromosome 7, 46,XX,7q+ (fig 3A, B). The karyotype of both parents was normal. No other cytogenetic abnormality was detected in the child's chromosomes. The banding patterns indicated that no chromosome 7 material was lost during the translocation although loss of a small region at the tip of $7 q$ is possible.

FISH

Fluorescent in situ hybridisation (FISH) with chromosome specific paint probes was performed using standard procedures. Whole chromosome microdissection probe pools ${ }^{24} 25$ from chromosomes $1,2,3,7$, and 21 were used. The chromosome 7 library probe indicated that one chromosome 7 did not have the signal extending completely to its long arm terminal end confirming the extra chromosome 7 material (results not shown). Closer examination also indicated that there was no visible reciprocal translocation of chromosome material from chromosome 7 to other chromosomes. Chromosome 21 microdissection probe pool was next used for chromosome painting because the patient's mental retardation is similar to that of trisomy 21 . However, the results (data not shown) indicated that the extra chromosomal material on $7 \mathrm{q}$ was not derived from chromosome 21 . Similarly, chromosome painting using whole chromosomes 1 and 2 library pools painted only chromosomes 1 and 2, respectively (data not shown). However, three signals were obtained when whole chromosome 3 library pool probe was used where both chromosomes 3 were fully painted and an additional signal was present on the terminal der(7q) (results not shown). 


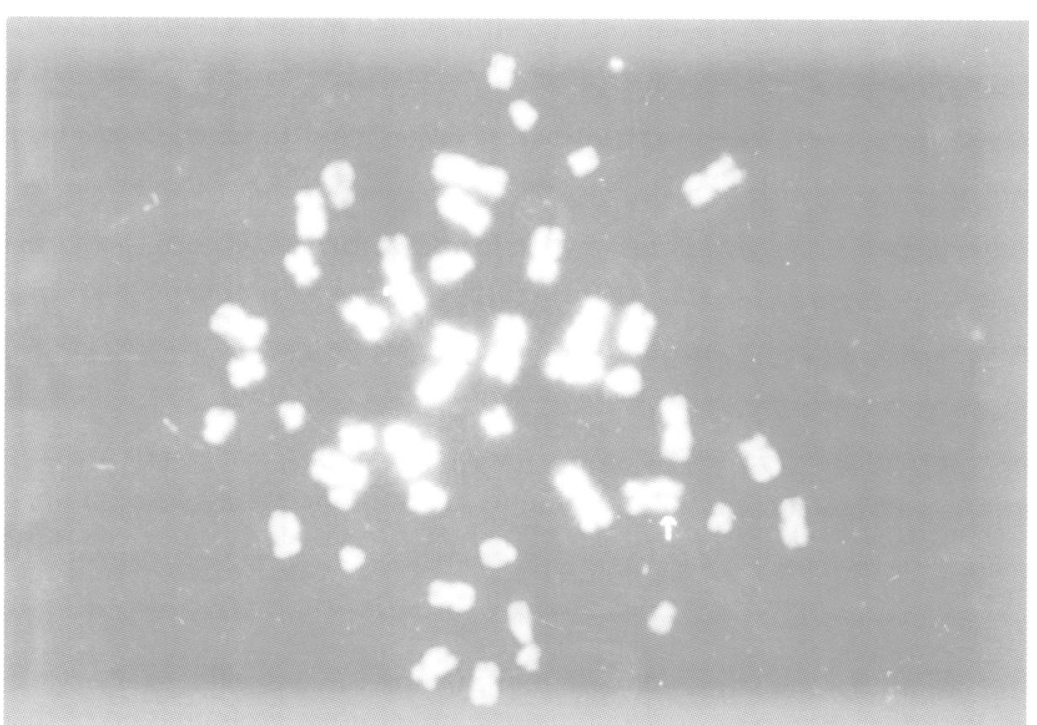

Figure 4 FISH with chromosome 3q26-qter specific probe. In addition to the signals from the normal chromosomes 3 , an additional signal was obtained at the terminal end of chromosome $7 q$ (indicated by an arrow) using the 3q26-qter microdissection probe pools.

The results of $\mathrm{G}$ banding (fig 3B) and FISH using chromosome 3 probe indicated that only the distal part (3q26-qter) of chromosome 3 may be involved in the duplication. Further FISH analysis was performed using microdissected chromosome band specific probe pool from 3q26-qter. The results confirmed that the additional material on $7 \mathrm{q}$ was derived from the region of 3q26-qter (fig 4). Since no extra chromosome painting signal was obtained with chromosome 7 library pool probe (see above), the additional 3q26-qter material on chromosome $7 \mathrm{q}$ was the result of an unbalanced translocation leading to trisomy 3q26-qter. The patient's karyotype was designated 46,XX, der(7)t(3;7)(q26-qter;7q+) de novo.

\section{Discussion}

The cumulative cytogenetic data for BPES cases have suggested overlapping chromosomal abnormalities in the $3 \mathrm{q} 22-\mathrm{q} 23$ region (reviewed recently in Jewett et $a l^{14}$ ). However blepharophimosis and ptosis have also been associated with the loss of $3 \mathrm{p} 25,{ }^{26}{ }^{28}$ suggesting genetic heterogeneity in patients with BPES. ${ }^{29}$ Recently, BPES in a large Indian pedigree was linked to chromosome 7p13-p21." Table 1 presents a summary of the spectrum of clinical features of BPES in association with known cytogenetic abnormalities compared to the features seen in our patient with trisomy 3q26qter. With the exception of unilateral ptosis and absence of epicanthus inversus, the physical features of the patient presented in this study show similarities to that of BPES patients. Other cases of BPES without epicanthus inversus have previously been reported. ${ }^{30} 31$

To our knowledge this is the first description of a partial trisomy for chromosome 3q26-qter that leads to blepharophimosis, ptosis, and mental retardation. Other reported cases of partial trisomy of the long arm of chromosome 3 are presented in table 2 and compared to our case. It is interesting that in two of these cases, ${ }^{32}{ }^{33}$ unilateral anomalies of the right eye, similar to those described here, are associated with partial trisomy for 3q. Additional pleiotropic features in BPES consisting of microcephaly, developmental retardation, primary amenorrhoea, premature ovarian failure, cryptorchidism, cleft palate, micrognathia, dental anomalies, pectus excavatum, brachycamptodactyly, and polythelia ${ }^{4-610111314163446}$ indicate the possibility of a contiguous gene syndrome. It is reasonable to suspect that reported cases of BPES with multiple anomalies associated with cytogenetic abnormalities are the result of a contiguous gene syndrome, whereas isolated cases of BPES with no cytogenetic rearrangements may be the result of a single gene defect. ${ }^{20}$ In our patient the region of trisomy which is distal to $3 q 22-q 23$ further suggests that BPES is genetically heterogeneous and the clinical features may indicate a contiguous gene syndrome encompassing at least one locus for eyelid development ${ }^{47}$ in chromosome 3q. It is possible that a small undetectable chromosomal loss from the distal tip of chromosome $7 \mathrm{q}$ may have contributed to the clinical features of the patient described here. However, cases involving partial deletion or monosomy for chromosome 7q34-qter show clinical features of Smith-Lemli-Opitz (SLO, MIM 270400') syndrome. ${ }^{48}$ SLO syndrome predominantly shows genitourinary abnormalities, cleft palate, and polydactyly. These features are not apparent in our patient though the microcephaly and mental retardation overlap in both diseases.

It is of interest that a number of candidate genes of significance to eye development have been mapped to the distal long arm of chromosome 3 . The retinol binding proteins RBP 1 and $R B P 2^{49}$ have been mapped to $3 \mathrm{q} 21$ q22 and 3q21-q25, respectively. Mouse mutants that are homozygous null in the RXRa retinoic acid receptor gene have smaller palpebral fissures than the wild type,${ }^{50}$ indicating that

Table 1 Summary of BPES associated phenotype involving chromosome deletions and balanced translocations

\begin{tabular}{|c|c|c|c|c|c|c|c|c|c|c|}
\hline Chromosome aberration & $\operatorname{del}(3 p)$ & $\operatorname{del}(3 q)$ & $\operatorname{del}(7 p)$ & $\operatorname{del}(7 q)$ & $t(2 ; 3)$ & $t(3 ; 4)$ & $t(3 ; 7)$ & $t(3 ; 8)$ & $\mathrm{t}(3 ; 11)$ & This study \\
\hline Chromosomal & & & & & $3 q 23$ & $3 \mathrm{q} 23$ & $3 q 23$ & $3 \mathrm{q} 23$ & $3 q 21$ & Trisomy \\
\hline breakpoints & $3 q$ ter- $3 p 25.3$ & $3 q 22-3 q 23$ & $7 \mathrm{p} 13-7 \mathrm{p} 15$ & 7 pter-7q34 & 2 pter- $2 \mathrm{q} 22$ & $4 \mathrm{p} 15$ & $7 q 23$ & $8 \mathrm{p} 21$ & $11 \mathrm{q} 23$ & 3q26-qter \\
\hline Blepharophimosis & + & + & + & + & + & + & + & + & + & $+(\mathrm{R})$ \\
\hline Ptosis & + & + & - & + & + & + & + & + & + & $+(\mathrm{R})$ \\
\hline Epicanthus inversus & + & + & + & + & + & + & + & + & + & - \\
\hline Microcephaly & + & + & + & + & NR & - & - & + & - & + \\
\hline Malformed ears & + & + & + & + & + & - & - & + & - & + \\
\hline Malformed palate & NR & + & - & + & NR & - & NR & + & NR & + \\
\hline Mental retardation & + & + & NR & + & + & - & - & + & - & + \\
\hline Growth delay & + & + & + & + & + & - & - & + & - & + \\
\hline Syndactyly of toes $2-3$ & NR & + & + & NR & + & - & NR & NR & NR & $+(\mathrm{R})$ \\
\hline Adduction of toe 1 & NR & + & + & NR & + & - & NR & NR & NR & $+(\mathrm{R})$ \\
\hline References & 29 & $11-16,29$ & 59 & 29 & 29 & 60 & 8 & 7 & 6 & \\
\hline
\end{tabular}


Table 2 Summary of clinical features associated with partial trisomy of $3 q$

\begin{tabular}{|c|c|c|c|c|c|c|c|}
\hline Chromosomal breakpoints & $3 q 21-q t e r$ & 3q21-qter & $3 q 22.1-q 24$ & $3 q 26$ & $3 q 25-q 28$ & 3q26.2-qter & This study \\
\hline Blepharophimosis & - & NR & - & - & & - & $+(\mathrm{R})$ \\
\hline $\begin{array}{l}\text { Ptosis } \\
\text { Ptinavolo }\end{array}$ & - & NR & - & - & NR & - & $+(R)$ \\
\hline Epicanthus inversus & - & - & - & - & - & - & - \\
\hline Anophthalmia & - & $+(\mathbf{R})$ & - & - & - & - & - \\
\hline Microcephaly & + & NR & - & NR & NR & NR & + \\
\hline Malformed ear & NR & + & - & + & + & + & + \\
\hline Malformed palate & NR & + & - & NR & + & + & + \\
\hline Syndactyly of toes $2-3$ & - & NR & - & - & NR & NR & $+(\mathrm{R})$ \\
\hline Adduction of toe 1 & - & NR & - & NR & NR & NR & $+(\mathrm{R})$ \\
\hline Talipes equinovarus & NR & + & - & NR & + & NR & - \\
\hline Clinodactyly of 5 th finger & + & + & + & NR & + & NR & - \\
\hline Mental retardation & NR & + & + & NR & + & + & + \\
\hline Growth delay & NR & + & - & + & + & NR & + \\
\hline Short, webbed neck & + & + & - & + & NR & + & + \\
\hline Hirsutism & NR & + & - & + & + & - & - \\
\hline Cataract & NR & NR & NR & + & NR & + & - \\
\hline Glaucoma & NR & NR & NR & + & NR & NR & - \\
\hline Coloboma of iris of eyes & $+(\mathrm{R})$ & NR & NR & NR & NR & NR & - \\
\hline References & 32 & 33 & 35 & 61 & 62 & 63 & \\
\hline
\end{tabular}

+ present; - absent; NR not reported; (R) observed only on the right side of the body.

retinoic acid signalling may play an important role in eyelid development. In addition, the ceruloplasmin (CP) gene has been mapped to 3 q23 and mutations in this gene give rise to excessive iron accumulation resulting in neurodegeneration of the retina and basal ganglia. ${ }^{51}{ }^{52}$ Another likely candidate is the HRY gene that has been mapped to $3 \mathrm{q} 28-\mathrm{q} 29^{53}$ and is the human homologue of the hairy gene in Drosophila. The protein product of the hairy gene is a participant in the Notch signalling pathway and is involved in segmentation and neural development during early Drosophila embryogenesis. ${ }^{55}$ The murine and rat homologues of this gene have been established to be important in eye development and morphogenesis. ${ }^{56-58}$ Additional studies will be necessary to determine the potential role(s) of these candidate genes in BPES.

The authors are grateful to the parents of the proband for their cooperation and permission to use the photographs and to $\mathrm{J} \mathrm{Fu}$ and $Y$ Young for excellent technical help.

1 McKusick VA. Mendelian inheritance in man. Baltimore: Johns Hopkins University Press, 1992:147-8

2 Stromme P, Sandboe F. 1996. Blepharophimosis-ptosisStromme P, Sandboe F. 1996. Blepharophimosis-ptosis-
epicanthus inversus syndrome (BPES). Acta Ophthalmol epicanthus inversus
Scand $1996 ; 74: 45-7$.

3 Zlotogora J, Sagi M, Cohen T. The blepharophimosis, ptosis, and epicanthus inversus syndrome: delineation of two types. Am f Hum Genet 1983;35:1020-7.

4 Oley C, Baraitser M. Blepharophimosis, ptosis, epicanthus inversus syndrome (BPES syndrome). $\mathcal{F}$ Med Genet 1988;25:47-51.

5 Fukushima Y, Wakui K, Nishida T, Ueoka Y. Blepharophimosis sequence and de novo balanced autosomal translocation $[46, \mathrm{XY}, \mathrm{t}(3 ; 4)(\mathrm{q} 23 ; \mathrm{p} 15.2)]$ : possible assignment of the trait to 3q23. Am F Med Genet 1991;40:485-7.

6 de Die-Smulders CE, Engelen J, Donk JM, Fryns JP. Further evidence for the location of the BPES gene at $3 \mathrm{q} 2 . \mathcal{F}$ Med Genet 1991;28:725.

7 de Almeida JC, Llerena JC Jr, Goncalves Neto JB, Jung M, Martins RR. Another example favouring the location of MPES at 3q2. F Med Genet 1993;30:86.

8 Boccone L, Meloni A, Falchi AM, Usai V, Cao A. Blepharophimosis, ptosis, epicanthus inversus syndrome, a new case associated with de novo balanced autosomal translocation [46,XY,t (3;7)(q23;q32)]. Am F Med Genet 1994;51:258-9.

Karimi-Nejad A, Karimi-Nejad R, Najafi H, Karimi-Nejad $\mathrm{MH}$. Blepharophimosis syndrome (BPES) and additional abnormalities in a female with a balanced X:3 translocation. Clin Dysmorphol 1996;5:259-61.

10 Alvarado $M$, Bocian $M$, Walker AP. Interstitial deletion of the long arm of chromosome 3: case report, review, and definition of a phenotype. Am $\mathcal{F}$ Med Genet 1987;27:781-6.

11 Fujita $H$, Meng J, Kawamura M, Tozuka N, Ishii F, Tanaka N. Boy with a chromosome del (3)(q12q23) and blepharophimosis syndrome. Am $\mathcal{F}$ Med Genet 1992;44:434-6.

12 Fryns JP, Stromme P, van den Berghe H. Further evidence for the location of the blepharophimosis syndrome (BPES) at 3q22.3-q23. Clin Genet 1993;44:149-51.

13 Ishikiriyama $S$, Goto $M$. Blepharophimosis sequence (BPES) and microcephaly in a girl with $\operatorname{del}(3)$ (q22.2q23) a putative gene responsible for microcephaly close to the BPES gene? Am $\mathcal{F}$ Med Genet 1993;47:487-9.
14 Jewett T, Rao PN, Weaver RG, Stewart W, Thomas IT, Pettenati MJ. Blepharophimosis, ptosis, and epicanthus inversus syndrome (BPES) associated with interstitial deletion of band 3q22: review and gene assignment to the interface of band 3q22.3 and 3q23. Am F Med Genet 1993;47:114750 .

15 Wolstenholme J, Brown J, Masters KG, Wright C, English CJ. Blepharophimosis sequence and diaphragmatic hernia associated with interstitial deletion of chromosome 3 (46,XY,del(3)(q21q23)). $\mathcal{f}$ Med Genet 1994;31:647-8.

16 Fryns JP. The concurrence of the blepharophimosis, ptosis, epicanthus inversus syndrome (BPES) and Langer type of mesomelic dwarfism in the same patient. Evidence of the location of Langer type of mesomelic dwarfism at $3 \mathrm{q} 22.3$ q23? Clin Genet 1995;48:111-12.

17 Amati P, Chomel JC, Nivelon-Chevalier A, et al. A gene for blepharophimosis-ptosis-epicanthus inversus syndrome maps to chromosome 3q23. Hum Genet 1995;96:213-15.

18 Harrar HS, Jeffery S, Patton MA. Linkage analysis in blepharophimosis-ptosis syndrome confirms localisation to 3q21-24. ₹ Med Genet 1995;32:774-7.

19 Lawson CT, Toomes C, Fryer A, et al. Definition of the blepharophimosis, ptosis, epicanthus inversus syndrome critical region at chromosome $3 \mathrm{q} 23$ based on the analysis of chromosomal anomalies. Hum Mol Genet 1995;4:963-7.

20 Small KW, Stalvey M, Fisher L, et al. Blepharophimosis syndrome is linked to chromosome 3q. Hum Mol Gene 1995;4:443-8.

21 Amati P, Gasparini P, Zlotogora J, et al. A gene for premature ovarian failure associated with eyelid malformation maps to chromosome 3q22-q23. Am 7 Hum Genet 1996;58:1089-92.

22 Messiaen L, Leroy BP, De Bie S, et al. Refined genetic and physical mapping of BPES type II. Eur f Hum Genet 1996; 4:34-8.

23 Hall JG, Froster-Iskenius UG, Allanson JE. Handbook of physical measurements. Oxford: Oxford University Press, 1989.

24 Deng HX, Yoshiura K, Dirks R, et al. Chromosome-bandspecific painting: chromosome in situ suppression hybridization using PCR products from a microdissected chromosome band as a probe pool. Hum Genet 1992;89:13-17.

$25 \mathrm{He}$ XX, Xia JH, Li LY, Dai HP, Zhu YH, Pan Q. Construction of chromosome 11q23-qter band-specific probe pool by microdissection. Chin Sci Bull 1994;39:162-4.

26 Merrild U, Berggreen S, Hansen L, Mikkelsen M, Henningsen K. Partial deletion of the short arm of chromosome 3 . Eur 7 Pediatr 1981;136:211-16.

27 Narahara K, Kikkawa K, Murakami M, et al. Loss of the 3 p25.3 band is critical in the manifestation of $\operatorname{del}(3 \mathrm{p})$ syndrome: karyotype-phenotype correlation in cases with deficiency of the distal portion of the short arm of chromosome 3. Am ₹ Med Genet 1990;35:269-73.

28 Mowrey PN, Chorney MJ, Venditti CP, et al. Clinical and molecular analyses of deletion 3p25-pter syndrome. Am Med Genet 1993;46:623-9.

29 Warburg M, Bugge M, Brondum-Nielsen K. Cytogenetic findings indicate heterogeneity in patients with blepharophimosis, epicanthus inversus, and developmental delay. $\mathcal{F}$ Med Genet 1995;32:19-24.

30 Maw M, Kar B, Biswas J, et al. Linkage of blepharophimosis syndrome in a large Indian pedigree to chromosome $7 \mathrm{p}$. Hum Mol Genet 1996;5:2049-54.

31 Temple IK, Baraitser M. Pitfalls in counselling of the blepharophimosis, ptosis, epicanthus inversus syndrome (BPES). F Med Genet 1989;26:517-19.

32 Fryns JP, van Eygen M, Logghe N, Van den Berghe H. Partial trisomy for the long arm of chromosome 3 [3(q21 qter) +$]$ in a newborn with minor physical stigmata. Hum Genet 1978;40:333-9.

33 Fear C, Briggs A. Familial partial trisomy of the long arm of chromosome 3 (3q). Arch Dis Child 1979;54:135-8.

34 Kohn R, Romano PE. Blepharoptosis, blepharophimosis, epicanthus inversus, and telecanthus-a syndrome with no name. Am $₹$ Ophthalmol 1971;72:625-32. 
35 Williamson RA, Donlan MA, Dolan CR, Thuline HC, Harrison MT, Hall JG. Familial insertional translocation of a portion of $3 \mathrm{q}$ into $11 \mathrm{q}$ resulting in duplication and deletion of region 3q22.1 leads to $\mathrm{q} 24$ in different offspring. $A m \mathcal{F}$ Med Genet 1981;9:105-11.

36 Ohdo S, Madokoro H, Sonoda T, Hayakawa K. Menta retardation associated cis and hypoplastic teeth. $\mathcal{F}$

37 de Die-Smulders CE, Droog RP, van Dijk M, Fryns JP. Severe intrauterine growth retardation, blepharophimosis, and cylindrical nose with midline groove: a new syndrome? f Med Genet 1993;30:525.

38 Wittebol-Post D, Hennekam RC. Blepharophimosis, ptosis polythelia and brachydactyly (BPPB): a new autosoma dominant syndrome? Clin Dysmorphol 1993;2:346-50.

39 Richieri-Costa A, Guion-Almeida ML, Rodini ES, Pereir SC, Cohen MM Jr. Newly recognized blepharofacioskeletal syndrome. Am $\mathcal{F}$ Med Genet 1993;46:620-2.

40 Clayton-Smith J, Krajewska-Walasek M, Fryer A, Donnai D. Ohdo-like blepharophimosis syndrome with distinctive facies, neonatal hypotonia, mental retardation and hypoplastic teeth. Clin Dysmorphol 1994;3:115-20.

41 Houlston RS, Ironton R, Temple IK. Association of atrial-ventricular septal defect, blepharophimosis, anal and radial defects in sibs: a new syndrome? Genet Couns 1994; 5:93-6.

42 Suri M, Kabra M, Verma IC. Blepharophimosis, telecanthus, microstomia, and unusual ear anomaly (Simosa synthus, microstomia, and unusual ear anomaly (Simosa
drome) in an infant. Am $₹$ Med Genet 1994;51:222-3.

43 Chismire KJ, Witkop GS. Optic nerve hypoplasia and angle dysgenesis in a patient with blepharophimosis syndrome.

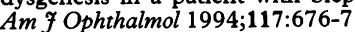

44 Nicolino M, Bost M, David M, Chaussain JL. Familia blepharophimosis: an uncommon marker of ovarian dysgenesis. F Pediatr Endocrinol Metab 1995;8:127-33.

45 Lee LR, Sullivan TJ. Blepharophimosis syndrome: association with colobomatous microphthalmos. Aust NZ $\mathcal{F ~ O p h - ~}$ thalmol 1995;23:145-7.

46 Elliott AM, Ludman M, Teebi AS. New syndrome? MCA/MR syndrome with multiple circumferential skin cres A 7 Med Genet 1996;62:23-5.

47 Smith A, Fraser IS, Shearman RP, Russell P. Blepharophimosis plus ovarian failure: a likely candidate for a contiguous gene syndrome. $\mathcal{F}$ Med Genet 1989;26:434-8

48 Berry R, Wilson H, Robinson J, et al. Apparent SmithLemli-Opitz syndrome and Miller-Dieker syndrome in family with segregating translocation $\mathrm{t}(7 ; 17)(\mathrm{q} 34 ; \mathrm{p} 13.1)$ Am $\mathcal{F}$ Med Genet 1989;34:358-65.

49 Defeo-Jones D, Huang PS, Jones RE, et al. Cloning of cDNAs for cellular proteins that bind to the retinoblastom gene product. Nature 1991;352:251-4.
50 Kastner P, Grondona JM, Mark M, et al. Genetic analysis of RXR alpha developmental function: convergence of RXR and RAR signaling pathways in heart and eye morphogenesis. Cell 1994;78:987-1003.

51 Klomp LW, Farhangrazi ZS, Dugan LL, Gitlin JD. Ceruloplasmin gene expression in the murine central nervous system. F Clin Invest 1996;98:207-15.

52 Klomp LWJ, Gitlin JD. Expression of the ceruloplasmin gene in the human retina and brain: implications for a pathogenic model in aceruloplasminemia. Hum Mol Genet 1996;5:1989-96.

53 Feder JN, Li L, Jan LY, Jan YN. Genomic cloning and chromosomal localization of HRY, the human homolog to the Drosophila segmentation gene, hairy. Genomics 1994;20: 56-61.

54 Ishibashi M, Sasai Y, Nakanishi S, Kageyama R. Molecular characterization of HES-2, a mammalian helix-loop-helix factor structurally related to Drosophila hairy and Enhancer of split. Eur f Biochem 1993;215:645-52.

55 Lardelli M, Ish-Horowicz D. Drosophila hairy pair-rule gene regulates embryonic patterning outside its apparent stripe domains. Development 1993;118:255-66.

56 Dehni G, Liu Y, Husain J, Stifani S. TLE expression correlates with mouse embryonic segmentation, neurogenesis, and epithelial determination. Mech Dev 1995;53:369-81.

57 Tomita $\mathrm{K}$, Ishibashi M, Nakahara $\mathrm{K}$, et al. Mammalian hairy and enhancer of split homolog 1 regulates differentiation of retinal neurons and is essential for eye morphogenesis. Neuron 1996;16:723-34.

58 Guillemot F. Analysis of the role of basic-helix-loop-helix transcription factors in the development of neural lineages in the mouse. Biol Cell 1995;84:3-6.

59 Bianchi DW, Cirillo-Silengo M, Luzzatti L, Greenstein RM. Interstitial deletion of the short arm of chromosome 7 without craniosynostosis. Clin Genet 1981;19:456-61.

60 Fukushima Y, Wakui K, Nishida T, Ueoka Y. Blepharophymosis (sic) syndrome and de novo balanced translocation $[46, \mathrm{XY}, \mathrm{t}(3,4)$ (q23;p15.2)]: possible localization of blepharophymosis (sic) syndrome. Am ₹ Hum Genet 1990;47:A29.

61 . Rosenbaum KN. Ocular findings in partial trisomy 3q Ophthal Paediatr Genet 1988;9:127-30.

62 van Essen AJ, Kok K, van den Berg A, et al. Partial 3q duplication syndrome and assignment of D3S5 to 3q25-3q28. Hum Genet 1991;87:151-4.

63 Rubbin SE, Nelson LB, Pletcher BA. Anterior polar cataract in two sisters with an unbalanced $3 ; 18$ chromosomal translocation. Am f Ophthalmol 1994;117:512-15. 